\title{
Tinjauan Maslahat al Mursalat Terhadap Penerapan Peraturan Menteri Agama Nomor 30 Tahun 2005 Tentang Wali Hakim Elfa Erfiana
}

Institut Agama Islam Negeri Ponorogo

Abstract: In the Minister of Religion Regulation Number 30 of 2005 concerning guardian judges in Article 2 Paragraph (1) concerning Guardian Judges in Article 2 paragraph (1) Bride and groom who are abroad and Article 3 Paragraph (3) regarding prospective brides residing in the region remote that uses a guardian judge. Because in the regulation it is explained that guardianship in marriage is the guardian of judges, both those who are abroad or those who are in remote areas. so the discussion about what the benefits or benefits provided for these regulations. Guardian judges are guardians appointed by the Minister of Religion or officials appointed by him and given the right and authority to act as marriage guardians. This research is a research on the application of the regulation of the Minister of Religion Number 30 of 2005 concerning the guardian of judges in terms of Maslahat al Mursalat or the benefits arising from the regulation on the Bride who is abroad and in remote areas. The method of this research is library research using qualitative method. Data collection techniques are documentation or data collection of research literature that uses books as a source of data related to the object of research. This research also uses other scientific sources that are relevant to the discussion of this research, such as dissertations, theses, journals and so on. Based on the results of the research carried out, it can be concluded that the review of maslahat al mursalat on the Regulation of the Minister of Religion Number 30 of 2005 concerning guardian judges for prospective brides who are abroad is maslahat hajiyat which means human problems needed by humans to eliminate the difficulties they face. For the prospective bride who is in a remote area is also a hajiyat benefit

Keywords: 
Abstrak: Dalam Peraturan menteri Agama Nomor 30 Tahun 2005 tentang wali hakim dalam Pasal 2 Ayat (1) tentang Wali Hakim dalam Pasal 2 ayat (1) Mempelai wanita yang berada di luar negeri dan Pasal 3 Ayat (3) tentang calon mempelai wanita yang berada di daerah terpencil yang menggunakan wali hakim. Karena dalam peraturan tersebut dijelaskan bahwa perwalian dalam pernikahan adalah wali hakim, baik mereka yang berada di luar negeri atau pun yang berada di daerah terpencil. sehingga pembahasan mengenai apa maslahat atau manfaat yang diberikan atas peraturan tersebut. Wali hakim adalah wali yang ditunjuk oleh Menteri Agama atau peabat yang ditunjuk olehnya dan diberi hak dan kewenangan bertindak sebagai wali nikah. Penelitian ini merupakan penelitian tentang penerapan peraturan Menteri Agama Nomor 30 Tahun 2005 tang tang wali hakim yang ditinjau dari Maslahat al Mursalat atau manfaat yang ditimbulkan dari peraturan tersebut terhadap Mempelai wanita yang berda di luar negeri dan daerah terpencil. Metode penelitian cini menggunakan penelitian pustaka menggunakan metode kualitatif . Teknik pengumpulan data adalah dokumentasi atau pengumpulan data literer penelitian yang menggunakan buku-nuku sebagai sumber datanya yang berkaitan dengan objek penelitian. Penelitian ini jga menggunakan sumbersumber ilmiah laainnya yang relevan dengan pembahasan penelitian ini, seperti skipsi,thesis,jurnal dan lain sebagainya. Berdasarkan hasil peneltian yang dilakukan dapat disimpulkan Tinjauan maslahat al mursalat terhadap Peraturan Menteri Agama Nomor 30 Tahun 2005 tentang wali hakim bagi calon mempelai wanita yang berada di luar negeri merupakan maslahat hajiyat yang berarti persoalan manusiayang dibutuhkan oleh manusia untukmenghilangkan kesulitan yang dihadapi. Terhadap calon mempelai wanita yang beraada di daerah terpencil juga merupakan maslahat hajiyat.

Kata Kunci: Daerah Terpencil, Luar Negeri, Maslahat al-Mursalat, Wali Hakim

\section{PENDAHULUAN}

Dalam Peraturan Menteri Agama Nomor 30 Tahun 2005 tentang wali hakim dijelaskan bahwa penetapan wali hakim pada Pasal 2 ayat 1 bagi mempelai wanita yang berada di luar negeri dan Pasal 3 ayat 3 bagi mempelai wanita yang berada di daerah terpencil. 
Wali nikah ialah seorang laki-laki yang memenuhi syarat Hukum Islam yakni muslim aqil, dan balig. Perwalian dalam pernikahan diwakili wali hakim untuk calon mempelai wanita yang hendak melaksanakan pernikahan apabila wali nasab tidak ada atau tidak mungkin menghadirkannya atau tidak diketahui tempat tinggalnya atau gaib atau enggan.

Adanya perbedaan dalam penerapan Peraturan Menteri Agama Nomor 30 Tahun 2005 pada kenyataannya orang yang melakukan pernikahan di luar negeri baik menggunakan wali dengan bantuan wali hakim ada beberapa syarat yang harus dipenuhi ${ }^{1}$. Diliha dari contoh kasus yang terjadi, jika menikah di luar negeri tanpa sepengetahuan keluaganya yang tidak mengetahui sebagai pihak dari wali nasab, juga menimbulkan beberapa masalah dalam keluarganya seperti hubungan keluarga akan renggang, terutama anak perempuan dengan ayahnya. Hal-hal seperti inilah yang menjadi masalah, bagaimana jika dilihat dari sisi Maslahat al Mursalah atau kemaslahatan dengan adanya pernikahan diluar negeri bagi calon wanita yang jauh dari wali nasab dan langsung digantikan oleh wali hakim.

Dengan fakta dalam Peraturan Menteri Agama Nomor 30 Tahun 2005 tersebut, maka peneliti menggunakan teoi Maslahat al Mursalat untuk mengetahui kemaslahatan yang ada dalam peraturan tersebut. Maslahat dalam arti bahasa yaitu setiap sesuatu, apa saja yang terdapat manfaat di dalamnya baik untuk memperoleh kemanfaatan, kebaikan maupun untuk menolak kemudharatan.

Sehingga dengan teori maslahat al mursalat tersebut bisa dilihat kemaslahatan atau kebaikan untuk calon mempelai wanita yang berada di luar negeri serta calon mempelai wanita yang berada di daerah terpencil. Masuk ke dalam kategori maslahat dharuriyah (kepentingan pokok), maslahat hajiyah (kemaslahatan yang dibutuhkan dalam menyempurnakan kemaslahatan pokok, atau maslahat tahsiniyat (kepentingan pelengkap). 
Beberapa penelitian yang menjelaskan tentang wali hakim terkait mempelai wanita yang berada di luar negeri dengan pasangannya dan mempelai wanita di daerah terpencil, antara lain:

1. "Studi Hukum Pernikahan Yang Dilaksanakan Oleh Wali Hakim Luar Negeri (Studi Kasus Di Mahkamah Syariah Negeri Kelantan) dengan kesimpulan bahwa keberadaan wali hakim dalam pernikahan dapat mengambil alih posisi wali nasab manakala wali nasab tersebut tidak ada. 98

2. Jurnal yang ditulis oleh Abdul Alim Ashidiqy dengan judul Imam Kampuang Sebagai Wali Hakim: Analisis Terhadap Putusan Pengadilan Agama Talu Nomor 50 /Pdt.G/20.PA. Tentang Isbat Nikah, yaitu pernikahan yang dilakukan oleh kedua pasangan yang berada di daerah jorong Padang Tujuh Nagari Auna Kauniang Kecamatan Pasaman Barat, dimana kedua pasangan itu tidak dinikahkan oleh wali nasab dan wali hakim,, tetapi dinikahkan wali kampuang yang sehari-hari bertindak sebagai imam dalam suatu kaum (suku) dalam susunan masyarakat disana.

\section{HASIL DAN PEMBAHASAN}

Menurut Idris Mulia, mendefinisikan pernikahan adalah "suatu perjanjjian suci yang kuat dan kokoh untuk hidup bersama secara sah antara laki-laki dan perempuan membentuk keluarga yang kekal, santun menyantuni, saling menyayangi, aman dan kekal. Dalam pernikhan yang suci, sahnya pernikhan yang harus dipenuhi, syarat dan rukun-rukunnya yaitu wali nikah merupakan rukun yang harus dipenuhi bagi calon mempelai wanita yang bertindak untuk menikahinya. Apabila tidak terpenuhi maka pernikhannya tidak sah. Karena keberadaan wali nikah merupakan suatu rukun, yang harus terpenuhi beberapa syarat.

Dalam Kompilasi Hukum Islam ayat (1) dirumuskan sebagai berikut: "yang bertindak sebagai wali nikah ialah seorang laki-laki yang memenuhi syarat Hukum Islam yakni muslim, aqil dan balig. Adapun urutan wali nikah sebagai berikut: 
a. Ayah

b. Kakek

c. Saudara Laki-laki

d. Saudara Laki-laki seayah

e. Anak laki-laki saudara laki-laki sekandung (keponakan)

f. Anak laki-laki dari saudara laki-laki seayah

g. Paman sekandung (maksudnya paman dari ayah yang seibu dan seayah) ${ }^{2}$

Apabila yang dimaksud diatas tidak bisa, barulah menggunakan wali hakim untuk calon mempelai waita yang hendak melaksanakan pernikahan. Dipertegas dalam pasal 23 ayat (1) Kompilasi Hukum Islam "wali nikah baru dapat bertindak sebagai wali hakim apabila wali nasab tidak ada atau tidak mungkin menghadirkannya atau gaib atau enggan. Apabila ayah calon mempelai wanita yang menjadi calon walinya pergi jauh merantau sehingga jaraknya dua marhalah atau lebih, maka yang menjadi wali nikahnya adalah :

a. Hakim (penghulu), apabila yakin wali aqrobnya (ayah sang gadis) belum diputuskan mati oleh hakim tersebut dan wali aqrobnya tidak menunjuk seorang wakil untuk menikahkan anak prempuannya.

b. Wali ab'ad (semisal kakaknya/adiknya), apabila wali aqrobnya diputuskan oleh hakim telah meninggal.

c. Wakil wali aqrob menunjuk wakil untuk menikahkan anak perempuannya.

d. Berkaitan dengan wali nikah, tidak semua orang bisa menggunakan wali nikah nasab yaitu ayah kandungnya. Banyak kasus yang terjadi seorang mempelai wanita menikah dengan menggunakan wali bukan dari silsilah keluarga ayahnya. Faktor yang melatarbelakanginya juga bermacammacam, mulai dari ayah yang sudah meninggal, tempat tinggal jauh, adlal, mafqud dan lain sebagainya. Wali nikah terakhir jika silsilah keluarga

2 Ahmad Rofiq, Hukum Islam Di Indonesia,(Jakarta: PT Rajagrafindo Persada), 8384. 
ayah ke atas seorang perempuan tidak ada, maka yang menjadi wali nikah yaitu wali hakim ${ }^{3}$.

Wali hakim adalah wali yang ditunjuk oleh Menteri Agama atau pejabat yang ditunjuk olehnya dan diberi hak dan kewenangan bertindak sebagai wali nikah. Istilah "luar negeri" adalah di luar wilayah atau kekuasaan atau daerah administrasi sebuah negara tersebut.

Kata maslahat al mursalat dalam pembahasan, perlu kiranya dikemukakan asal kedua kata tersebut dan pengertiannya menurut ulama:

a. Menurut bahasa, kata maslahat berasal dari bahasa Arab dan telah dibakukan ke bahasa Indonesia menjadi kata maslahat yang berarti mendatangkan kebaikan atau membawa manfaat dan atau menolak kerusakan. Menurut bahasa aslinya, kata maslahat mursalat berasal dari kata sāluhā,yāsluhu, salahan, صلح، artinya sesuatu yang baik, patut dan bermanfaat. ${ }^{4}$ Sedang kata maslahat artinya terlepas bebas, tidak terikat dengan dalil agama (al-qur'an dan al-hadist) yang membolehkan atau yang melarangnya.

b. Menurut Dr. Muhammad Yusuf maslahat mursalat yaitu segala kemaslahatan yang tidak diatur oleh ketentuan Syari dengan mengakuinya atau menolaknya akan tetapi mengakuinya dengan menarik manfaat dan menolak kerusakan.

Lebih lanjut secara spesifik pengertian dan ruang lingkup berlakunya metode maslahat al mursalat ini telah dibahas oleh Dr. Jalaludin Abdul Rahman dalam bukunya Al-masalih maslahat wa makanatuhafi al-Tasyri' yang diantaranya menyatakan :

"Maslahat yang berlaku di kalangan ahli bahasa Arab yaitu setiap perbuatan yang bisa mendatangkan kemanfaatan bagi manusia, kata maslahat adalah bentuk tunggal dari kata mashalih

${ }^{3} \mathrm{Abu}$ An'im , Referensi Penting Amaliyah NU \& Problematika Masyarakat, (Kediri: Mu'jiat Manivestasi Santri Jawa Barat, 2010) 368.

${ }^{4}$ Muhibbin, Kemaslahatan dan Pembaharuan Hukum Islam,(Semarang :Walisongo Press, 2008), 15. 
yang berarti setiap kebaikan (kepentingan hidup mansia) lawan dari kerusakan. Dikatakan baik jika dapat mendatangkan kemanfaatan/ kemaslahaan yakni dengan hal-hal yang baik dan yang benar.

Bagi Allah yang telah memperlihatkan kemaslahatan mahlukNya dalam asal usul, akhirat dan pengidupan mereka lantas mengabaikan kemaslahatan mereka dalam hukum-hukum syara. Karena hukum syara bersifat lebih umum, maka lebih utama untuk dipertahankan. Karena hukum syara juga merupakan bagian dari kemaslahatan hidup mereka (di dunia ini), sebab ia merupakan sarana untuk mengamankan harta, darah dan kehormatan mereka dan tidak akan ada kehidupan tanpanya,maka harus ditegaskan bahwa Allah memperlihatkan kemaslahatan dalam masalah hukum untuk mereka 5 .

Jika telah tegas bahwa Allah memperhatikan kemaslahatan maka, tidak boleh mengabaikannya dalam situasi apapun. Jika teks ijma dan sumber-sumber hukum lainnya sejalan dengan kemaslahatan manusia maka tidak ada persoalan akan tetapi jika sumber hukum bertentangan dengannya,maka harus ada upaya harmonisasi dengan cara yang telah disebutkan yaitu dengan membatasi validitas sumber hukum tersebut ada kasus-kasus tertentu. Dalam sinaran maslahat dan memberikan prioritas terahir melalui jalan penjelasan (al-bayan).

Sedangkan kata maslahat menurut Dr. Jalaludin Abdur Rahman diartikan dengan melepaskan atau lepas dari pertimbangan syari. Jadi maslahat al mursalat menurut beliau adalah :

"Adapun yang dimaksud dengan maslahat al-mursalat yaitu sesuatu yang sunyi dari semacam dalil, tetapi dalam suatu waktu hal tersebut sesuai dengan ibarat-ibarat syari secara keseluruhan baik, tujuan-tujuan atau hukumnya". Kemudian mengenai ruang lingkup berlakunya, maslahat al-mursalat dibagi atas 2 bagian yaitu :

Al maslahat al Dharuriyah (kepentingan-kepentingan yang esensi dalam kehidupan) seperti memelihara agama, memelihara jiwa,akal, keturunan dan harta. Maslahat al Hajiyyah (kepentingan-kepentingan

5 ibid., 
esensial dibawah derajatnya al maslahat Dharuriyyah). Namun diperlakukan dalam kehidupan manusia agar tidak mengalami kesukaran dan kesempitan, jika tidak terpenuhi akan mengakibatkan kerusakan dalam kehidupan serta akan mengakibatkan kesempitan kesukaran baginya. Maslahat al -Tahsiniyyah (kepentingankepentingan pelengkap), jika tidak terpenuhi maka tidak akan mengakibatkan kesempitan dalam kehidupannya, sebab ia tidak begitu membutuhkan hanya sebagai pelengkap atau hiasan hidupnya. Untuk menetapkan apakah sesuatu itu mengandung maslahat atau tidak, diperlukan penelitian mendalam dari berbagai segi dan melakukan pertimbangan yang mendalam atau kemanfaatan dan kemadharatannya, dengan kriteria-kriteria yang sesuai dengan tuuan-tujuan syariat.

Alam mengistimbatkan hukum kurang dibedakan antara qiyas, istihsan, dan maslahat al mursalat, yang pertama tidak ada nashnya, karena itu belum ditetapkan hukumnya, sedang dengan yang kedua ada nashnya dan telah ditetapkan hukumnya. Pada istihsan hanya ada satu peristiwa, tetapi ada dalil yang dapat dijadikan sebagai dasarnya ${ }^{6}$.

Dalil yang pertama lebih kuat dari yang kedua, tetapi karena ada sesuatu kepentingan dipakailah dalil yang kedua. Sedang pada maslahat al mursalat hanya ada satu peristiwa dan tidak ada dalil yang dapat dijadikan dasar untuk menetapkan hukum peristiwa itu, tetapi ada suatu kepentingan yang sangat besar jika peristiwa itu ditetapkan hukumnya, karena itu ditetapkanlah hukum berdasar kepentingan tersebut.

Sejalan dengan pengertiannya, maka syarat umum maslahatal mursalat adalah ketik tidak ditemukan nash sebagai bahan rujuan selanjutnya Imam Malik menganjukan syarat-syarat khususnya yaitu:

1. Adanya persesuaian antara maslahat dipandang sebagai sumber dalil yang berdiri sendiri dengan tujuan-tuuan syariat (maasid as syariah) dengan adanya persyaratannya ini berati tidak boleh

${ }^{6}$ Ahmad Sanusi, Ushul Figh,(Depok : PT Rajagrafindo Persada, 2015),80. 
maslahat menegaskan sumber dalil yang lain, atau bertentangan dengan dalil yang qathi'. Akan tetapi harus sesuai dengan maslahat -maslahat yang memang ingin diwujudkan oleh syari.

2. Maslahat itu masuk akal (rationable), pemikiran yang rasional.

3. Penggunaan dalil maslahat ini adalah dalam rangka menghilangkan kesulitan yang terjadi (raf'u haraj lazim). Dalam pengertian, seandainya maslahat yang dapat diterima akal itu tidak dapat diambil, niscaya manusia akan mengalami kesulitan?

Klasifikasi maslahat dari berbagai aspek, para ahli usul fiqh mengemukakan beberapa pembagian maslahat jika dilihat dari brbagai segi. Dilihat dari segi kandungan maslahat para ulama ushul fiqh membaginya menjadi dua bagian : Pertama, maslahat al Ammah, yang kemaslahatan umum yang menyangkut kepentingan orang banyak. Kedua, maslahat al-khassah, kemaslahatan pribadi, dan ini sangat jarang sekali seperti kemaslahatan yang berkaitan dengan pemutusan hubungan perkawinan seseorang yang dinyatakan hilang (mafqud).

Dilihat dari segi kualitas dan kepentingan kemaslahatan itu, para ahli ushul figh membaginya kepada tiga macam, yaitu:

1. Maslahat Dharuriyyah (kepentingan primer), yaitu kemaslahatan yang berhubungan dengan kebutuhan pokok umat manusia di dunia dan diakhirat. Kemaslahatan yang seperti ini ada lima, yaitu memelihara agama, memelihara jiwa, memelihara akal, memelihara keturunan dan memelihara harta. Kelima kemaslahatan ini disebut al-mashalih al khamsah.

2. Maslahat Hajiyajh (kepentingan sekunder), yaitu kemaslahatan yang dibutuhkan dalam menyempurnakan kemaslahatan pokok (mendasar) sebelumnya yang berbentuk keringanan untuk mempertahankan dan memelihara penyangga dan penyempurna bagi kepentingan primer.

${ }^{7}$ Moh Mufid, Ushul Figh Ekonomi dan Keuangan Kontemporer, (Jakarta: Prenadagroup, 2016), 119. 
3. Maslahat Tahsiniyyah (kepentingan pelengkap), yaitu kemaslahatan yang sifatnya pelengkap berupa keleluasaan yang dapat melengkapi kemaslahatan sebelumnya.

Menurut Al-Ghazali, semua pemeliharaan tersebut umumnya dijamin oleh teks Perundang-undangan dan karena itu sejalan dengan iyas yang lazim. Jika hal itu bukan suatu kasus, maka maslahat menentukan hanya ketika ada pertimbangan yang menyakinkan dan tegas mempengaruhi masyarakat secara keseluruhan. Jika dilarang maka namanya istihlah atau maslahat mursalah $^{8}$.

Ketiganya membentuk satu struktur yang saling berhubungan dan juga menganalisis dua aspek dalam hubungan yang satu dengan yang lain, artinya pertimbangan usur pelengkap (Hajiyyah) tidak boleh membolehkan pada tujuan asal atau primer atau Dzaruriyyah ${ }^{9}$.

Oleh sebab itu, maka pelengkap (tahsiniyyah) merupakan unsur penyempurna bagi kepentingan sekunder (hajiyayyah) dan penopang, kepentingan primwr. Inilah yang membuat tercetusnya rumusan lima ketentuan, yaitu:

a. Maslahat Dzaruriyyah merupakan asal bagi semua kepentingan yang lain

b. Kerusakan pada kepentingan primer, berarti sesuatu kerusakan bagi kepentingan yang lain

c. Kerusakan pada kepentinan yang lain, tidak harus berarti merusak pada kepentingan primer.

d. Dalam kasus-kasus tertentu, kerusakan pada kepentingan sekunder atau pelengkap, dapat berakibat rusaknya kepentingan primer.

e. Perlindungan atas kepentingan sekunder dan pelengkap, harus dilakukan untuk mencapai kepentingan primer ${ }^{\mathbf{1 0}}$.

\footnotetext{
8 Abdullah Ahmed An Na'im, Deontruksi Syariah, (Yogyakarta : LKIS, 1997), 50.

${ }_{9}$ Asmawi, Studi Hukum Islam Dari Tekstual-Rasionalis), 113.

10 ibid.,
} 
Sedangkan jika dilihat dari sisi akomodasinya dengan komunitas lingkungan, maslahat terbagi menjadi dua, yaitu:

a. Maslahat yang dapat beradaptasi dengan perubahan ruang,, waktu dan lingkungan sosial, sebab objjek utamanya adalah mua'malah (masalah sosial kemasyarakatan dan hukum-hukum kebiasaan (adat).

b. Maslahat yang berwatak konstan. Hal ini tidak dapat dirubah hanya karena perubahan lingkungan, sebab hanya berkaitan dengan persoalan-persoalan ibadah mahdah atau keagamaan.

Dalam rangka memperjelas pengertian maslahat al mursalat itu, Abdul Karim Zaidan menjelaskan macam-macam maslahat :dilihat dari keberadaan maslahat menurut syara' terbagi tiga, yaitu:

1. Al-Maslahat al Mu'tabarah (maslahah) yang ditunuk langsung oleh al-uran atau Sunnah Rasulullah Saw), yaitu kemaslahatan yang didukung oleh syara. Adanya dalil khusus yang menjadi dasar bentuk dan jenis kemaslahatan tersebut. Misalnya, diperintahan berjihad untuk memelihara agama dari rongrongan musuhnya, diwajibkan hukuman qisahash untuk menjaga kelestarian jiwa, ancaman hukuman atas peminum khamar untuk memelihara akal, ancaman zinauntuk memelihara kehormatan dan keturunan serta ancaman hukum mencuri untuk menjaga harta.

2. Al- Maslahat al mulgah (maslahah) yang bertentangan dengan teks wahyu, yaitu kemaslahatan yang ditolak oleh syara. Atau sesuatu yang dianggap maslahah oleh akal pikiran, tetapi kenyataannya bertentangan dengan ketentuan syariat. Misalnya anggapan bahwa menyamakan pembagian warisan antara anak laki-laki dan anak wanita adalah maslahat. Akan tetapi, kesimpulan seperti itu bertentangan dengan ketentuan syariat. Adanya pertentangan itu menunjukkan bahwa apa yang diaanggap maslahat, itu bukan maslahat di sisi Allah.

3. Al-maslahat al-Mursalat (maslahah) yang secara tegas tidak bertentangan dengan wahyu atau hadith dan juga tidak mendukungnya), yaitu kemaslahatan yang keberadaannya tidak 
didukung syara dan tidak pula dibatalkan atau ditolak syara melalui dalil yang perinci. Kemaslahatan dalam bentuk ini terbagi dua, yaitu al-maslahah al-gharbah, yaitu kemaslahatan yang asing atau kemaslahatan .11

Ulama ushul fiqh sepakat mengatakan bahwa al maslahat almutabarah dapat dijadikan hujjah (alasan) dalam menetapkan hukum Islam. Kemaslahatan seperti ini termasuk dalam metode qiyas. Mereka juga sepakat mengatakan bahwa al maslahat al mulgah tidak dapat dijadikan landasan hukum Islam, demikianjjuga dengan almaslahat al-gharibiyah karena tidak ditemukan dalam praktek. Adapun terhadap kehujahan al-maslahat al-mursalat pada prinsipnya jumhur ulama mazhab menerimanya sebagai salah satu alasan dalam menetapkan hukum syara', sekalipun mereka berbeda pendapat dalam menentukan syarat penerapan dan penetapannya.

Yang menjadi objek malsahat al mursalat, ialah kejadian atau peristiwa yang perlu ditetapkan hukumnya, tetapi tidak ada satu pun nash (Al-quran dan hadith) yang dapat dijadikan dasarnya. Prinsip ini disepakati oleh kebanyaan pengikut mazhab yang ada dalam fiqh, demikian pernyataan Imam Al-arafi Ath-Thufi dalam kitabnya, maslahat al mursalat menerangkan hukum dalam bidang muamalah dan semacamnya sedang dalam soal-soal ibadah adalah Allah untuk menetapkan hukmnya, karena manusia tidak sanggup mengetahui dengan lengkap hikmah ibadah itu. Oleh sebab itu, hendaklah kaum muslimin beribadah sesuai dengan ketentuannya yang terdapat Al-uan dan hadith. Abd Wahab Khallaf berpendapat suatu maslahat hendaknya jangan bertentangan dengan nash atau ijma, suatu maslahah hendaknya tidak hanya untuk kepentingan individu, tetapi maslahat itu bersifat umum (universal). Suatu maslahat itu tidak berdasarkan perkiraan semata, tetapi benarbenar hakiki adanya, setelah dengan usaha sungguhsungguh melakukan pembahasan yang mendalam. Pada saai ini banyak metode istislah

11 Sulaiman Abdullah, Sumber Hukm Islam Permaslahan,122. 
tau maslahat al mursalat yaitu problematika hukum yang timbul kemudian karena tidak ada kejelasan dalam nah diktum larangan atau membolehkannya. ${ }^{12}$

Maslahat al-mursalat dapat menjadi hujjah atau dalil menurut sebagian ulama Imam Malik dan sebagian ulama Syafi'iyah, tetapi harus memenuhi syarat-syarat yang telah ditentukan oleh ulamaulama ushul. Jumhur Hanafiyyah dan Syafiiyah mensyaratkan di bawah qiyas yaitu bila terdapat hukum ashl yang dapat di-qiyashkan kepadanya dan juga terdapat 'illat mudhabit (tepat), sehingga dalam hbungan hukum itu terdapat tempat untuk merealisir kemaslahatan.

Berdasarkan pemahaman ini, mereka berpegang pada kemaslahatan yang dibenarkan syara tetapi ereka lebih leluasa dalam mengangap maslahat yang dibenarkan syara ini, karena luasnya pengetahuan mereka dalam soal pengakuan syari (Allah) terdapat illat sebagai tempat bergantungnya hukum, yang merealisasikan kemaslahatan. Hal ini hampir tidak ada maslahat al mursalat yang tidka memiliki dalil yang mengakui kebenarannya. ${ }^{13}$

Syarat-Syarat berhujjah dalam Maslahat al mursalat untuk menjadikan maslahat al mursalat sebagai hujjah harus memenuhi 3 syarat, yakni:

a. Maslahat tersebut haruslah maslahat yang haqiqi (sejati), bukan hanya yang berdasarkan wahm (perkiraan) saja. Artinya bahwa membina hukum berdasarkan kemaslahatan itu haruslah benarbenar dapat membawa kemanfaatan dan menolak kemudharatan. Akan tetapi kalau hanya sekedar berdasarkan perkiraan akan adanya kemanfaatan dengan tidak mempertimbangkan kemudharatan yang bakal timbul, maka pembinaan hukum yang semacam itu adalah berdasarkan wahm saja dan tidak dibenarkan oleh syariat.

b. Kemaslahatan itu hendaklah kemaslahatan yang umum, bukan kemaslahatan yang khusus untuk perseorangan. Karena itu harus

\footnotetext{
12 Abd Salam Arif, Pembaharuan Pemikiran Hukum Islam Antara Fakta dan Realitas Kajian Pemikiran Hukum Syaikh Mahmud Syaltut (Yogyakarta : LESFI, 2003), 56.

13 Sulaiman Abdullah, Sumber Hukum Islam Permslahaan dan Fleksibilitasnya, (Jakarta :

Sinar Grafika Offset, 2007),126.
} 
dapat dimanfaatkan oleh banyak orang atau dapat menolak kemudharatan yang menimpa kepada banyak orang.

c. Kemaslahatan itu tidak bertentangan dengan dasar-dasar yang telah digariskan oleh nash atau ijma. Oleh karena itu tidak dianggap kemaslahatan mempersamakan anak laki-laki dengan anak perempuan dalam menerima warisan. ${ }^{14}$

Jumhur ulama sepakat bahwa maslahat al mursalat adalah bukan dalil yang berdiri sendiri. Maslahat al mrsalat tidak terlepas dari petunjuk syara. Ulama tidak akan menggunakan maslahat al mursalat dalam menghukumi sesuatu meskipun itu mendatangkan manfaat menurut tinjaun akal dan sejalan dengan tujuan syara (mendatangkan kemaslahatan) ${ }^{\mathbf{1 5}}$.

Karena hukum syara bersifat lebih umum, maka lebih utama untuk dipertahankan. Maka lebhih utama untuk dipertahankan. Hukum syara juga merupakan bagian dari kemaslahatan hidup (di dunia ini), ebab ia merupakan sarana untuk mengamankan harta, darah dan kehormatan mereka dan tidak akan ada kehidupan tanpanya, maka harus ditegaskan bahwa Allah mempertahankan kemaslahatan dalam masalah hukum untuk mereka.

Jika telah tegas bahwa Allah mempertahatikan kemaslahatan, maka tidak boleh mengabaikannya dalam situasi apapun. Jadi jika teks, ijma dan sumbersumber hukum lainnya sehalan dengan kemaslahatan manusia, maka tidak ada persoalan. Akan tetapi, jika sumber hukum bertentan ${ }^{16}$ gan dengannya, maka harus ada upaya harmonisasi dengan cara yang telah disebutkan di atas, yaitu dengan membatasi validitas sumber hukum tersebut pada kasus-kasus tertentu dengan sinaran maslahat dan memberikan prioritas tersebut terahir melalui jalan penjelasan (al bayan).

Sementara itu menurut para pemikir hukum Islam dalam menanggapi penggunaan malsahat al mursalat sebagai dalil syariah ini, mereka bersifat tawasut (tidak menolak sepenuhnya, tapi juga

\footnotetext{
14 Ibid.,107.

15 Sapiudin Shidiq, Ushul Fiqh, (Jakarta : Kencana, 2017),89.

16 Sulaiman Abdullah, Sumber Hukum Islam, 108.
} 
tidak mempermudah penggunaannya). Hal ini sebagaimana dikatakan Yusuf Al-Qardlowy, bahwa tidak mungkin terjadi dalam syariat yang telah pasti, ada suatu hukum yang bertentangan dengan maslahat mahkluk atau terdapat hukum yang membahayakan mereka.

Jadi nash al qur'an atau hadith dianggap sebagai maslahat yang dibatalkan dan tidak boleh dipergunakan, karena nash al-quran itulah yang dijadikan dasar untuk ibadah kepada Allah swt. Dan secara kenyataan maslahat yang bertentangan dengan nash, apabila direnungkan secara mendalam dan dianalisa secara detail, maka bukanlah maslahat yang hakiki, melainkan maslahat yang belm pasti dan dihiasi para pelakunya oleh sifat kekurangan, kelengahan , hawa nafsu atau tindakan ikut-kutan dengan orang lain ${ }^{17}$.

Dalam Peraturan Menteri Agama Nomor 30 Tahun 2005 tentang wali hakim pasal 1 ayat (1) menjelaskan antara lain: wali hakim adalah Kepala Kantor Urusan Agama Kecamatan yang ditunjuk oleh Menteri Agama untuk bertindak sebagai wali nikah bagi calon mempelai wanita yang tidak mempunyai wali. Bab II tentang Penetapan wali hakim pasal 2 yaitu :

1. Bagi calon mempelai wanita yang akan menikah di wilayah Indonesia atau di luar negeri / wilayah teritorial Indonesia, tidak mempunyai wali nasab yang berhak atau wali nasabnya tidak memenuhi syarat, aau mafqud atau berhalangan atau adlal, maka pernikahannya dilangsungkan oleh wali hakim.

2. Khusus untuk menyatakan adlalnya wali sebagaimana tersebut pada ayat (1) pasal ini ditetapkan dengan keputusan Pengadilan Agama / Mahkamah Syariyah yang mewilayahi tempat tinggal calon mempelai wanita ${ }^{18}$.

Bab III tentang penunjukan dan kelima kedudukan pasal 3 yaitu :

1. Kepala Kantor Urusan Agama (KUA) dalam wilayah kecamatan yang bersangkutan ditunjuk menjadi wali hakim untuk

\footnotetext{
17 Teungku Muhammad Hasbi Ash Shidieqy, Pokok-pokok Pegangan Imam Mazhab,(Semarang : PT Pustaka Riki Putra, 1997), 43.

18Peraturan Menteri Agama Nomor 30 Tahun 2005 Pasal 2 ayat (1)
} 
menikahan mempelai wanita sebagaimana dimaksud dalam pasal 2 ayat (1) peraturan ini.

2. Apabila Kepala KUA Kecamatan sebagaimana dimaksud pada ayat (1) berhalangan atau tidak ada, maka Kepala Seksi yang membidangi tugas Urusan Agama Islam atas nama Kepala Kantor Depatemen Agama kabupaten/kota diberi kuasa atas nama Menteri Agama menunjuk salah satu penghulu pada kecamatan tersebut atau terdekat untuk sementara menjadi wali hakim dalam wilayahnya.

3. Bagi daerah terpencil atau sulit dijangkau oleh transportasi, maka Kepala Seksi yang membidangi tugas Urusan Agama Islam atas nama Kepala Departemen Agama menunjuk pembantu penghulu pada kecamatan tersebut sementara menjadi wali hakim dalam wilayahnya ${ }^{19}$.

Adapun faktor-faktor yang menyebabkan terjadinya pernikahan di luar negeri yaitu pertama, ketika seorang wali tidak mengiinkan anak perempuannya menikah dengan laki-laki pilihannya, maka inilah yang mengakibatkan terjadinya pernikahan di luar negeri tanpa mengetahui prosedur yang benar. Keengganan wali menerima pilihan anaknya juga bisa disebabkan karena perbedaan kasta antar pasangan, dimana wali tersebut sudah memiliki pasangan yang sesuai dengan anaknya, maka inilah pemicu dimana wali merasa bahwa pilihan anaknya tidka tepat karena menurut wali laki-laki pilihan anaknya tidak sanggup menjamin masa depan untuk anak perempuannya ${ }^{20}$.

Di sisi lain, para pekerja wanita pendidikannya yang kurang sehingga banyak wanita yang bekerja di luar negeri sebagai asisten rumah tangga di luar negeri, dan ketika pulang kampung tidak jarang mereka (para pekerja wanita) membawa anak dari hasil pernikahannya di luar negeri, entah itu diketahui oleh keluarganya,

\footnotetext{
19 Peraturan Menteri Agama Nomor 30 Tahun 2005 Pasal 3

20 Abu An'im, Referensi Penting Amaliyah NU, 91.
} 
atau tidak, tetapi mereka (para pekerja wanita) banyak melakukan pernikahan di tempat merekaaa bekerja tanpa diketahui oleh keluaganya, meskipun keluarganya yang berhak menjadi walinya masih ada. Sehingga ketika wanita tersebut memiliki anak dari hasil pernikahan tersebut perempuan, akan sulit menentukan wali nikah ketika dia telah menajdi dewasa dan mau nikah. ${ }^{21}$

Di samping itu tidak jarang mereka (para pekerja wanita ) menikah dengan sesama pekerja yang tidak jelas asal-usulnya dan tidak jelas juga keberadaannya. Kejadian pernikahan seperti itu banyak terjadi, meskipun diantara mereka telah mendapatkan surat nikah,namun surat nikah abal-abal. Contohnya, ketika dalam kondisi di mana seorang ayah kandung tidak bisa hadir dalam sebuah akad nikah, maka dia bisa mewakilkan hak perwaliannya kepada orang lain yang dipercayainya, meksi bukan termasuk urutan dalam daftar orang yang berha menjadi wali. Sehingga bila akad nikah akan dilangsungkan di luar negeri dan semua pihak sudah ada kecuali wali, karena dia tinggal di Indonesia dan kondisi tidak memungkinkannya untuk ke luar negeri, baik dari segi biaya atau pun kesehatan wali nasab, maka dia boleh mewakilkan hak perwaliannya kepada orang yang sama tinggal di luar negeri untuk menikahkan anak perempuannya, atau wali hakim ${ }^{22}$.

Jika ditelaah dari adnaya ketentuan wali hakim (sultan) yang menggantikan wali nasab, maka diketahui bahwa esensi legalitas kewenangan wali hakim (sultan) itu muncul lantaran fungsi dan persetujuan wali nasba sebagai simbol pennagung jawab (pemegang kuasa) seorang perempuan, tidak dapat diketahui.

Nsmun jika akan menjadi wali dalam urutan sudah tidak ada atau tidak memungkinkan, maka jalan terakhir untuk menjadi wali dalam pernikahan adalah menggunakan wali hakim, dan wali hakim

\footnotetext{
21 Jazari, Tidak Sahnya Perwalian, 60.

22 Ety Murtingah, Analisis Hukum islam Terhadap Prktik Pernikahan dengan Melakukan Wali Hakim Orang Tua Berada Di luar negeri di Desa Dampul Timur Kecamatan Jrengik Kabupaten Sampang,Skripsi, 69.
} 
baru bisa digunakan jika memang wali sahnya tidak ada yang bisa menikahkannya ${ }^{23}$.

Wakil dalam akad nikah hanya berkedudukan sebagai duta yang menyatakan sesuatu atas nama yang mewakilkan, yang diberi wewenang oleh wali nikah (muwakil) untuk menikahkan calon mempelai wanita. Namun, untuk menghindari terjadinya hal-hal yang tidak di inginkan di kemudian hari. dilakuan secara tertulis dan dipersaksikan oleh orang lain. Pada dasarnya taukil wali nikah dapat terjadi secara lisan.

Dengan demikian, fungsi yang dimiliki oleh wali hakim baik berdasarkan Hukum Islam maupun hukum positif pada akhirya adalah sama, yaitu sama-sama sebagai pengganti wali nasab atau wali arqab yang tidak dapat melaksanakan tugasnya disebabkan oleh halangan dari pribadi masing-masing wali tersebut ${ }^{24}$.

Mengenai wali hakim bagi calon mempelai wanita yang berada di daerah terpencil, dalam pelaksanaan isbat nikah yang dilakukan oleh Pengadilan Agama yang merupakan pengesahan atas pernikahan yang terjadi antara seorang pria dan wanita. Pengucapan ijab itu dilafalkan oleh laki-laki yang bukan wali nasab namun beliau adalah seorang imam kampung pada suatu kaum yang bertugas membantu dalam masalah keagamaan yang lebih spesifik dalam masalah imam shalat sebagaimana halnya dengan jabatan pembantu yang lain, bilal dan khatib.

Kasus yang menyebabkan imam kampung bertindak sebagai wali nikah sekaligus menjadi wali hakim dikarenakan seorang wanita yang akan menikah tersebut tidak memiliki seorang pun wali nasab yang berhak untuk menjadi wali nikah. Sepasang pria dan wanita tersebut mengurus kehendak pernikahannya tidak resmi melalui antor Urusan Agama Kecamatan setempat, maka untuk memudahkan urusan, mereka mendatangi imam kampung itu disebabkan imam tersebut sering membantu masyarakat yang ingin

\footnotetext{
23 Jazari , Tidak sahnya Perwalian, 67.

${ }^{24}$ Ety Murtingah, Analisis Hukum islam Terhadap Prktik Pernikahan dengan Melakukan Wali Hakim Orang Tua Berada Di luar negeri di Desa Dampul Timur Kecamatan Jrengik Kabupaten Sampang,Skripsi, 64.
} 
melaksanakan nikah di bawah tangan. Pada akhirnya calon istri menyerahkan urusan perwaliannya kepada imam tersebut.

Kronologis imam kampung disematkan kepadanya wali hakim oleh sekelumit masyarakat adalah diawali dengan terdapatnya beberapa kasus pernikhan yang terjadi di luar pengawasan Pegawai Pencatat Nikah pada kantor Urusan Agama setempat ${ }^{25}$.

Wali nikah sering menyerahkan urusan ijab dengan berwakil kepada imam kampung untuk melafalkan ijab. Sehingga dengan seringnya ia terlibat mewakili pelafalan ijab, maka muncul anggapan masyarakat awam bahwa imam kamung sudah berada pada posisi sebagai wali hakim. Padahal justru sebatas penerima wakil dalam pelafan ijab.

Pengangkatan imam kampung sebagai wali hakim dalam sebuah pernikahan tidak didasarkan kepada alasan yang dibenarkan oleh syara, karena secara substansi Islam dan hukum positif yang berlaku di Indonesia adalah pemerintah atau orang yang di tauliyahkan adalah pemerintah untuk menjadi wali hakim.

Sakralitas norma dan lembaga negara yang awalnya memiliki tujuan mulia akan terganggu dengan sikap remeh kepada norma, lembaga dan petugas negaradalam menangani pernikahan. Melihat mafsadah yang muncul sebagai akibat dari putusan Pengadilan Agama maka hal itu penting untuk dihindari. Hal ini sesuai dengan kaidah fikih,"menolak kerusaan atau madharat lebih utama daripada mendapatkan kemaslahatan". 26

Perwalian nasab atau kerabat pindah kepada wali hakim, yang berupa seorang atau lembaga seperti kepala KUA apabila :

1. Wali nasab memang tidak ada

2. Wali nasab bepergian jauh atau tidak ditempat, tetapi tidak memberi kuasa kepada wali yang lebih dekat yang ada di tempat, seperti memberi kuasa kepada adik atau kakak lelakinya.

\footnotetext{
${ }^{25}$ Abdul Karim Ashdiqy, Imam Kampuang Sebagai Wali Hakim Analisis Trhadap Putuasn Pengadilan Agama Talu Nomor 502/Pdt.G/2011/PA/Tentang Isbat Nikah,02, (2018), 162 26 ibid.,168.
} 
3. Wali nasab kehilangan hak perwaliannya, misalnya berbeda agama

4. Wali nasab menolak bertindak sebagai wali

5. Wali nasab menjadi mempelai laki-laki dari perempuan di bawah perwaliannya, seperti seorang yang mestinya menjadi walinya akan tetapi wanita yang dinikahinya adalah adik sepupunya sendiri.

Wali hakim memiliki pengetahuan sama dengan Qadi, wali hakim disini termasuk Qadi di Pengadilan. Seseorang yang berhak menjjadi wali hakim adalah: pemerintah, khalifah, atau Qadi nikah yang di beri kewenangan dari kepala negara untuk menikahkan wanita yang berwali hakim ${ }^{27}$. Tata cara melakukan pernikahan dengan wali hakim, permohonan wali hakim karena tidak ada:

1. Membuat permohonan wali hakim bermaterai, kepada Kepala Kantor Urusan Agama sesuai wilayah yurisdiksinya.

2. Membaca permohonan tersebut sesaat menjelang akad nikah.

Al wakalah adalah adalah penyerahan urusan seseorangkepada orang lain (wakilnya) untuk melaksanakan suatu urusan, kemudian wakil tersebut menempati posisi yang mewakilkan (muwakil) dalam hak dan kewajiban yang berlaku dengan kesempatan ${ }^{28}$.

Kriteria daerah terpencil yaitu daerah yang sulit dijangkau karena berbagai sebab, seperti keadaan geografi (kepulauan, pegunungan, daratan,hutan dan rawa), transportasi, sosial dan ekonomi. Kawasan-kawasan terpencil memiliki beberapa tipe, antara lain:

1. Tipe A (Terpencil karena ketiadaan Sarana Aksebelitas) yaitu kawasan pedesaan yang terisolasi oleh sebab tidak tersedianya Sarana Aksebelitas menghubungkan kawasan tersebut dengan Pusat Pertumbuhan.

27 Miss Nurhasila Kufima, Faktorfaktor Pembolehan Perwalian,59.

28 ibid., 
2. Tipe B (Terpencil karena jarak) yaitu kawasan pedesaan yang terisolasi oleh sebab secara geografis jaraknya jauh dari Pusat Pertumbuhan.

3. Tipe C (Terpencil karena isolasi Goografis), yaitu kwasan pedesaan yang terisolasi oleh sebab keberadaan isolasi geografis yang memisahkan kawasan tersebut dengan Pusat Pertumbuhan.

4. Tipe D (Terpencil karena alasan khusu), yaitu kawasan pedesaan yang terisolasi oleh sebab khusus, misalnya pengaruh adat istiadat, sehingga memisahkan diri. ${ }^{29}$

Tinjauan maslahat al mursalat terhadap Penetapan Peraturan Menteri Agama Nomor 30 Tahun 2005 tentang wali hakim bagi calon mempelai wanita yang berada di luar negeri. Arti wali hakim luar negeri adalah pengganti wali nikah yang ditunjuk olehnya, yang diberikan hak dan kewenangan untuk bertindak sebagai wali nikah di wilayahnya bagi pihak-pihak yang datang dari luar wilayah dan kewenangannya telah disahkan oleh wali hakim lain.

Dalam Peraturan Menteri Agama Nomor 30 Tahun 2005 pasal 2 ayat (1) Pejabat yang dimaksudkan adalah Kantor Urusan Agama (KUA) Kecamatan, dan atau Pembantu Pegawai Pencatat Nikah (P3N) oleh Kepala Seksi Urusan Agama Islam (Kasie URAIS) Kabupaten/ kota di wilayah Indonesia atau atas nama Menteri Agama menunjukkan menjadi wali hakim untuk sementara apabila ternyata KUA berhalangan atau tidak ada, dan pegawai yang memenuhi syarat menjadi wali hakim pada perwakilan Republik Indonesia di luar negeri ${ }^{30}$. Dan apabila wali nasab tidak bisa menjadi wali nikah bagi anak perempuannya yang berada di luar negeri, disebabkan tidak memiliki biaya, sakit atau pun halangan lain, amka perwalian nikah oleh wali hakim.

Kemaslahatan dalam penunjukan wali hakim bagi calon mempelai wanita yang berada di luar negeri merupakan maslahat yang bersifat maslahat hajiyat ialah persoalan-persoalan yang

${ }^{29}$ Direktoral Jenderal Ciptakarya, "Identifikasi Lokasi Desa Terpencil" Dalam Ciptakarya.Pu.Go.Id, (Diakses Pada Tanggal 3 Maret jam 07.24.

30 Peraturan Menteri Agama Nomor 30 Tahun 2005 Pasal 2 ayat (1) 
dibutuhkan oleh manusia untuk menghilangkan kesulitan dan kesusahan yang dihadapi. Di antara ketentuan hukum yang disyaratkan untuk meringankan dan memudahkan kepentingankepentingan manusia ialah semua keinginan yang dibawa oleh ajaran Islam.

Tinjauan maslahat al mursalat terhadap Penerapan Peraturan Menteri Agama Nomor 30 Tahun 2005 tentang wali hakim bagi calon mempelai wanita yang berada di daerah terpencil yang terjadi kampung-kampung dan berada di daerah yang sulit dijangkau oleh transportasi, maka Kepala Seksi yang membidangi tugas Urusan Agama Islam atas nama Kepala Departemen Agama menunjuk pembantu penghulu pada kecamatan tersebut untuk sementara menjadi wali hakim dalam wilayahnya.

Sehingga kemaslahatan bagi mempelai wanita yang berada di daerah terpencil bersifat maslahat hajiyat yaitu maslahat yang dibutuhkan untuk tercapainya kebutuhan-kebutuhan dan terhindarnya segala bentuk kesulitan hidup ${ }^{31}$. Maslahat hajiyat memang penting dan dibutuhkan dan harus dipelihara, tetapi jika tidak dapat dilakukan, hanya menimbulkan kesulitan bagi manusia dan tidak sampai pada rusaknya kehidupan. Maslahat hajjiyat (kamaliyat) adalah kemaslahatan yang diperlukan untuk kelapangan dan keluasan yang jika kemaslahatan tersebut tidak terwujud kelangsungan hidup masih dapat dipertahankan hanya saja akan datang kesulitan dan kesempitan ${ }^{32}$.

Apabila ditinjau dalam teori terkait dengan keterangan Peraturan Menteri Agama Nomor 30 Tahun 2005 pasal 3 ayat (3) dengan adanya peraturan tersebut bertujuan untuk memberikan kemudahan kepada masyarakat terutama bagi yang akan menikah calon-calon mempelai wanita yang berada di daerah terpencil sesuai dengan teori maslahat al mursalat. Dalam kaidah fiqih asasi yaitu meraih kemaslahatan dan menolak kemafsadatan. 'Izzudin bin Abd

${ }^{31}$ Malthuf Siroj, Pradigma Ushul Fiqih Negosiasi Konflik Antara Maslahah dan Nash, (Yogyakarta : CV Pustaka Ilmu Grup, 2013).

32 Romli Studi Perbandingan Ushul Fiqih,( Yogyakarta : Pustaka Pelajar, 2014),223. 
al Salam di dalam kitabnya Qawaid al Ahkam fi Muslhalih al anam mengatakan bahwa seluruh syariah itu adalah maslahat yang dinilai akal sehat betul-betul sejalan dengan tujuan Allah dalam menetapkan hukum. Yang dinilai akal sehat sebagai suatu maslahat yang tujuan Allah dalam menetapkan hukum itu tidak berbenturan dalam nash yang telah ada. Serta maslahat itu diamalkan dalam kondisi yang memerlukan arti kalau tidak akan ditempuh mendatangkan kesulitan dalam kehidupan ${ }^{33}$.

Di beberapa kampung terpencil menjadikan kiyai atau tokoh agama setempat untuk menjadi wali hakim tanpa adanya surat perintah dari Kantor Urusan Agamasetempat. Tetapi setelah adanya penetapan keabsahan imdneganam kampung sebagai wali hakim oleh Pengadilan Agama Talu, sehingga sudah resmi untuk menjadi wali bagi calon mempelai wanita yang sudah tidak memiliki wali nasab.

Seperti dalam contoh kasus yang terjadi di Pengadilan Agama Bukit Tinggi kasus yang menyebabkan imam kampung bertindak sebagai wali nikah sekaligus wali hakim dikarenakan seorang wanita yang akan menikah tersebut tidak memiliki seorang pun wali nasab yang berhak untuk menjadi wali nikah ${ }^{34}$.

Sepasang pria dan wanita tersebut mengurus kehendak pernikahannya tidak resmi melalui Kantor Urusan Agama Kecamatan setempat, amak untuk memindahkan urusan mereka mendatangi imam kampung tersebut. Dikarenakan imam kampung tersebut sering membantu masyarakat yang ingin melaksanakan nikah di bawah tangan. Pada akhirnya calon istri menyerahkan urusan perwaliannya kepada imam tersebut.

Pada sebagian kecil masyarakat yang berada di jambu baru ada yang menyakini bahwa imam kampung itu sudah bisa dianggap sebagai wali hakim. Walaupun faktanya mayoritas masyarakat yang berada di sana enggan mengakuinya. Kronologis imam kampung

${ }_{33}$ Amir Syarifudin, Garis-garis Besar Ushul Fiqih,(Jakarta : Kencana Prenada Grup, 2012),67.

34 Abdul Alim Ashdiqiy, Imam Kampuang Sebagai Wali Hakim Terhadap Putusan Pengadilan Agama Talu Nomor 57/Pdt.G11/PA,2018),161. 
disematkan kepada wali hakim oleh sekelumit masyarakat adalah dengan diawalinya dengan terdapat beberapa kasus pernikahan yang terjadi di luar pengawasan Pegawai Pencatat Nikah pada Kantor Urusa Agama Kecamatan (nikah siri). Wali nikah sering menyerahkan urusan ijab dengan berwakil kepada imam kampung unruk melafalkan ijab, maka muncul anggapan masyarakat awam bahwa imam kampung sudah berada di posisi wali hakim. Padahal justru hanya sebatas penerima wakil dalam pelafalan ijab ${ }^{35}$.

Dalam suatu wawancara imam kampung membenarkan hal tersebut. Ia beralasan demi membantu orang yang tidak memiliki wali maka sebagai imam kampung berpendapat sah saja untuk menjadi wali nikah dengan posisi wali hakim. Karena wanita tersebut telah menyerahkan perwaliannya kepada dirinya. Sehingga anggapan masyarakat yang tumbuh di wilayah tersebut sebagai wali hakim memiliki tingkat kepercayaan yang baik sehingga terpercaya untuk menyerahkan urusan agama termasuk persoalan menjjadi wali hakim. Dalam hal ini di istilahkan dengan Living Law yang hidup dalam masyarakat sekitar. Selain itu majlis hakim tetap membenarkan bahwa prinsip wali hakim adalah pemerintah. Namun, untuk kasus tertentu yang ditunjuk pemerintah seperti imam kampung yang dipercaya sudah dapat dikatakan sebagai wali hakim.

Usaha mewujudkan maslahat ini dapat dilakukan dengan dua cara. Pertama, aktif dengan melakukan segala sesuatu yang mendukung terwujudnya maslahat tersebut. Kedua, pasif meninggalkan segala sesuatu yang dapat menggangu perwujadannya ${ }^{36}$.

Peraturan Menteri Agama Nomr 30 tahun 2005 tentang wali hakim pasal 2 ayat (3), menjelaskan bahwa tauliyah pengangkatan wali hakim itu harus melalui surat resmi dari Kantor Kementerian Agama Kabupaten Kota yang akan menunjuk siapa diantara

\footnotetext{
35 ibid.,162.

${ }^{36}$ Malthuf Siroj,Pradigma Ushul Fiqih Ngosiasi Konflik Antara Maslahah dan Nash,(Yogyakarta ;CV Pustaka Ilmu Grup, 2013), 30.
} 
penghulu yang ada di wilayah tersebut yang akan menjadi wali hakim, selama wali hakim (Kepala KUA Kecamatan yang definitif) yang berhalangan.

Begitu pula untuk calon memepelai wanita yang berada di daerah terpencil jika langsung diberikan kepada wali hakim harus melalui prosedur yang berlaku yakni jika telaah diberikan surat resmi dari pihak KUA untuk menunjuk penghulu atau PPN untuk mewakili Kepala KUA sebagai wali hakim, jika tidak bisa hadir dalam pernikahan sebagai wali hakim. Sesuai dengan penjelasan dalam Peraturan Menteri Agama Nomor 30 Tahun 2005 pasal 4 ayat (3) bahwa Kepala Seksi yang membidangi tugas Urusan Agama Islam atas nama Kepala Departemen Agama menunjuk pembantu penghulu pada kecamatan tersebut untuk sementara menjadi wali hakim dalam wilayahnya.

Setiap hukum yang ditetapkan oleh Allah dalam Al-quran begitu pula yang ditetapkan Nabi dalam sunnahnya mengandung unsur maslahat dalam tinjauan akal, baik dalam bentuk mendatangkan manfaat atau kebaikan yang diperoleh oleh manusia ataupun menghindarkan kerusakan dari manusia ${ }^{37}$.

\section{KESIMPULAN}

Tinjauan maslahat al mursalat terhadap Penerapan Peraturan Menteri Agama Nomor 30 tahun 2005 tentang wali hakim bagi calon mempelai wwanita yang berada di luar negeri merupakan maslahat hajiyat yang berarti persoalan-persoalan yang dibutuhkan oleh manusia untuk menghilangkan kesulitan dan kesusahan yang dihadapi. Penunjukan wali hakim yang diwaliki oleh pemerintah sebagai penguasa tersebut memberikan kemudahan bagi calon mempelai untuk menikah meskipun berada di luar negeri, akan tetapi tetap bisa menjalankan pernikahan secara sah, baik dari segi agama maupun negara.

Tinjauan maslahat al mursalat terhadap calon mempelai wanita yang berada di wilayah terpencil juga merupakan maslahat hajiyat

37 Amir Syarifudin, Garis-Garis Besar Ushul Figh, 66. 
yaitu ketentuan hukum yang disyaratkan untuk meringankan ddan memudahkan kepentingan-kepentingan manusia ialah semua keringanan yang dibawa oleh ajaran Islam. Memberikan kemudahan bagi mempelai di kampung setempat yang mempercayai imam kampung menjadi wali hakim dari pihak alam pernikahan yang juga telah mendapatkan keabsahan dari Pengadilan Agama untuk menikahkan. Selain pihak Kantor Urusan Agama Kecamatan setempat.

Berdasarkan hal-hal yang telah diuraikan maka sarannya pertama yaitu perlu adanya pemahaman terutama agama kepada setiap terpencil, yang memang belum paham mengenai fiqih munakahad. Selain itu pihak KUA bisa memberikan edukasi terhadap masyarakat akan pentingnya pemahaman wali nikah, beserta aturan yang berlaku. Kedua perlu adanya koordinasi dari sektor pemerintahan, pejabat desa, tokoh masyarakat untuk memberikan pemahaman akan pentingnya wali dalam pernikahan. Baik bagi warga negara Indonesia yang berada di luar negeri atau pun masyarakat umum, wajib diberikan pemahaman perihal syarat wajib menikah dalam syariat serta hukum negara Indonesia. Sehingga perkara seperti ini bisa diminimalisir, termasuk bagi calon wanita yang berada di luar negeri.

\section{DAFTAR PUSTAKA}

Abdullah, Sulaiman, Sumber Hukum Islam Permslahaan dan Fleksibilitasnya, Jakarta : Sinar Grafika Offset, 2007,126.

Abdul Karim Ashdiqy, Imam Kampuang Sebagai Wali Hakim Analisis Trhadap Putuasan Pengadilan Agama Talu Nomor 502/Pdt.G/2011/PA/Tentang Isbat Nikah,02, (2018), 162 ibid.,168.

An'im, Abu, Referensi Penting Amaliyah NU \& Problematika Masyarakat, Kediri: Mu'jiat Manivestasi Santri Jawa Barat, 2010, 368.

Ahmed An Na'im, Abdullah ,Deontruksi Syariah, Yogyakarta : LKIS, 1997, 50. 
Asmawi, Studi Hukum Islam Dari Tekstual-Rasionalis,113.

Ety Murtingah, Analisis Hukum islam Terhadap Prktik Pernikahan dengan Melakukan Wali Hakim Orang Tua Berada Di luar negeri di Desa Dampul Timur Kecamatan Jrengik Kabupaten Sampang,Skripsi, 69.

Muhibbin, Kemaslahatan dan Pembaharuan Hukum Islam,Semarang :Walisongo Press, 2008, 15.

Mufid, Moh, Ushul Fiqh Ekonomi dan Keuangan Kontemporer, Jakarta: Prenadagroup, 2016, 119

Malthuf Siroj, Pradigma Ushul Fiqih Negosiasi Konflik Antara Maslahah dan Nash, Yogyakarta : CV Pustaka Ilmu Grup, 2013.

Nurhasila Kufima, Miss ,Faktorfaktor Pembolehan Perwalian, 59.

Direktoral Jenderal Ciptakarya, "Identifikasi Lokasi Desa Terpencil" Dalam Ciptakarya.Pu.Go.Id, (Diakses Pada Tanggal 3 Maret jam 07.24.

Rofiq, Ahmad, Hukum Islam Di Indonesia,Jakarta: PT Rajagrafindo Persada, 83-84.

Romli, Studi Perbandingan Ushul Fiqih,Yogyakarta : Pustaka Pelajar, 2014,223.

Sanusi, Ahmad, Ushul Figh,Depok : PT Rajagrafindo Persada, 2015,80. Salam Arif, Abd, Pembaharuan Pemikiran Hukum Islam Antara Fakta dan Realitas Kajian Pemikiran Hukum Syaikh Mahmud Syaltut Yogyakarta : LESFI, 2003, 56.

Shidiq, Sapiudin, Ushul Figh, (Jakarta : Kencana, 2017),89.

Muhammad Hasbi Ash Shidieqy, Teungku ,Pokok-pokok Pegangan Imam Mazhab,Semarang : PT Pustaka Riki Putra, 1997, 43.

Syarifudin, Amir ,Garis-garis Besar Ushul Fiqih,(Jakarta : Kencana Prenada Grup, 2012,67.

Siroj, Malthuf ,Pradigma Ushul Fiqih Ngosiasi Konflik Antara Maslahah dan Nash,Yogyakarta ;CV Pustaka Ilmu Grup, 2013, 30.

Jazari, Tidak Sahnya Perwalian,60.

Peraturan Menteri Agama Nomor 30 Tahun 2005 Pasal 2 ayat (1)

Peraturan Menteri Agama Nomor 30 Tahun 2005 Pasal 3. 